This chapter was accepted for publication in Ciocca R., Srivastava N. (eds) Indian Literature and the World. Palgrave Macmillan, London, 2017. DOI: 10.1057/978-1137-54550-3_3

\title{
Reading Together: Hindi, Urdu, and English village novels
}

Francesca Orsini (SOAS)*

\section{Reading Together}

How to do a multilingual history of the novel, and why should we even attempt such an enterprise? In her essay "The aesthetics and politics of "reading together" Moroccan novels in Arabic and French', Karima Laachir lays out the reasons for such an enterprise in the context of Morocco, and several of her arguments are pertinent to North India, too. The multilingual literary field in Morocco is largely disconnected and polarized betweeen Arabic and French, what Abdelfattah Kilito calls 'split tongue' and 'split literature'. This unproductive dichotomy extends to the study of Arabic and French literature, which draws upon ideological views of Arabic as the 'national' language and French as 'foreign' (Laachir, 2015: 8). In critical discourse, the novel has been seen simplistically as a 'foreign import' from French, in the process obscuring, Laachir argues, both its strong ties to pre-modern Moroccan genres such as travel-writing, letter-writing and mixed prose, as well as the more complex trajectory of circulation between Arabic fiction writing in the Mashreq (Egypt and Lebanon in particular) and the Maghreb (Morocco, Algeria, and Tunisia) (2015: 9-10). Moreover, while the first generation of post-independence Maghrebi writers in French may have agonized over their use of the coloniser's tongue, the following generation assertively reclaimed French as a Maghrebi language, acculturated and subverted it to serve their own purposes, not just to 'write back' to the former colonizers but also to communicate to each other (Laachir, 2015: 6). Finally, while the Arabic novel is understood as having been shaped by French and other European novels, Maghrebi novels in French are supposedly untouched by Arabic writing traditions.

All these arguments easily find echo in North India, where Hindi, Urdu, and English are considered separate literary worlds, a trend that academic study has only tended to reinforce. Here, too, the 'influence' of English or European literature over Hindi and Urdu is accepted as systemic, while the suggestion that English literature in India is affected by literatures in Hindi and Urdu is hardly ever made.

To remedy this unfortunate dichotomy and the blind spots it produces, Laachir suggests an 'entangled comparative reading' which actively looks for common ground and traces of mutual influence (2005: 11). She draws attention to the strong relationship that Moroccan novels in French and Arabic maintain with their 'maternal culture' and with oral traditions in the context of decolonization, and the dialogue they establish with each other in aesthetic and social terms (Laachir 2015: 9-11). In the case of multilingual North India, these are propositions that seem best posed as

\footnotetext{
* Research for this essay was undertaken as part of the project "Multilingual Locals and Significant Geographies" funded by the European Research Council (ERC) under the European Union's Horizon 2020 research and innovation programme under grant agreement No 670876.
}

erc 
questions and hypotheses rather than as factual statements. So rather than positing that Hindi, Urdu and Indian English novels have been shaped by the multilingual oral world and vernacular and oral traditions, and have been in dialogue with one another, this essay approaches these as questions. Have they been in dialogue with each other? Do they incorporate the same aspects of the multilingual oral world (which in this case includes Avadhi, Bhojpuri, Hindi, Urdu, and English), and the same vernacular and oral traditions? Do they shape the social world in their narratives in similar ways, or do different concerns and tensions animate and structure them? And finally, to what extent do we need to read these novels and their generic choices in the context of the trends and debates within each literary field? The 'entangled comparative reading' that this essay attempts is therefore one that looks for common ground and mutual constitution and puts in dialogue novels in the contiguous languages of Hindi, Urdu and English. Language, education, literary habitus and aesthetics, social position, literary debates and political currents-all constitute a complex matrix along which we can read writers' individual narrative, stylistic and ideological choices.

After outlining the geographical setting of the novels, the essay first briefly discusses what can be considered a common point of departure, Premchand, before analysing each novel and ending with an extended comparison.

\section{Purab/Awadh}

The focus of this particular comparison is on novels of rural and village life, even more specifically novels set in the eastern part of the Gangetic plain which goes under the name of Purab (= East) or, for a slightly more limited area, Awadh. Awadh as a region was split between rich agricultural tracts, under the control of both Hindu and Muslim rent-collectors-turned-feudal landowners (zamindars, or larger taluqdars, rural gentry who were often called Raja whether Hindu or Muslim), and small towns (qasbas) that were centres of Indo-Persian culture and of Sufi networks attracting both Hindu and Muslim disciples and pilgrims. In the eighteenth and nineteenth centuries, late-Mughal Iranian Nawabs made Lucknow, their capital, one of the richest cities in India, a sophisticated and thriving centre of elite craftsmen, traders, and cultural specialists — including the famous, and famously wealthy, courtesans. ${ }^{\dagger}$ After decades of increasing fiscal pressure, Awadh was annexed by the East India Company in 1856, just one year before it was engulfed in the great rebellion of 1857 , whose suppression caused a dramatic physical reconfiguration of the city and the dispersal of many of its cultural specialists to other centres. In the colonial period, Awadh became one of the centres of nationalist politics, including the peasant revolt in 1920-22, but also one of the areas most affected by the Pakistan movement and Partition, with many of its middle-class and elite Muslims migrating to Pakistan. After independence, rural Awadh was among the areas most affected by the legislation abolishing zamindari and by agricultural underdevelopment. ${ }^{\ddagger}$

\footnotetext{
$\dagger$ Awadh, the Persian name for Ayodhya, was also the name of a province first under the Delhi Sultans and then under the Mughals; it became an autonomous sub-imperial region in the eighteenth- and nineteenth centuries, and it is this Nawabi Awadh, with its capital in Lucknow, that is now remembered as 'Awadh'.

$¥$ As Vikram Seth’s novel, A Suitable Boy, explains in detail, security of tenancy and the abolition of intermediaries between farmers and the state, what became known as zamindari abolition, was already discussed in the decades before independence, particularly by Congress Socialists. After 1947, this was one of the first major legislative efforts of Nehru's Congress government and a central plank of his prospected land reform, despite the fact that zamindars had joined Congress in great numbers already before independence and were largely opposed to it. A 'state' rather than central matter, the Zamindari
} 
In cultural terms, urban Awadh - the city of Lucknow-has been celebrated with nostalgia for its sophisticated poetic, musical, and material culture, epitomized by the glamourous (and glamourized) figure of the courtesan. Rural Awadh, by contrast/comparison, has been both celebrated for its composite culture (called Ganga-Jamuni from the meeting of the two rivers) consisting of Hindu-Muslim/Sufi shared devotion and festivals, and physical culture, and also decried for its exploitative agrarian, caste, and patriarchal system. Modern attitudes thus range from nostalgia for its rich and shared aural, ritual and material culture of songs, festivals, and food, to despair at its chronic underdevelopment and lack of social and gender justice.

The choice of focusing on Hindi, Urdu, and English novels on rural Awadh in this essay was not just dictated by expediency, then - the fact that thematic comparison is always possible and productive even between unrelated texts and genres. The three novels discussed in this essay were written over the course of thirty years and focus on different periods in the modern history of rural Awadh. Shivaprasad Singh's Hindi novel Alag alag vaitarani [Many Vaitarnis] (1967) is set in a village in the early 1950s, post-independence and post-zamindari; ${ }^{\S}$ Qazi Abdus Sattar's Urdu novel Shab gazida [Bitten by the Night] (1988) is set on a large rural estate before independence, in the early 1940s; ** and Vikram Seth's A Suitable Boy (1993), set in 1951-52, at the cusp of zamindari abolition, features a substantial rural subplot as one of its parallel narratives. How each novel deals with the zamindari system and its abolition and with the culture of rural Awadh also signals its relation to broader issues of national imagination and state-building and the rhetoric of development in postcolonial India, to issues of caste, gender, and the minoritization of Muslims, and to particular cultural sensibilities and aesthetics. Does the choice of realism, for example, carry the same meaning in the Hindi novel from the 1960s, the 1980s Urdu one, and the English one? First, though, it will be useful to consider the first Hindi-Urdu writer to write systematically about the rural world of north India,

\footnotetext{
Abolition Act and Land Reform Act of 1951 had to be ratified by the different states legislatures and was bitterly contested, as the novel also details. Seth espouses the view that the Act had symbolic rather than real consequences, given that zamindars found ways of circumvent this and the Land Ceiling Act. It was supposed to have hit harder Muslim zamindars, already in a difficult position after Partition and the migration of many of them to Pakistan had made their hold on joint family properties more liable to contestation, as indeed the Seth's novel shows. In a short story by Qazi Abdus Sattar, 'Malkin', the widow of one such Muslim zamindar, remains alone and destitute in the ancestral home after independence, assisted only by her faithful old Hindu retainer, Chaudhri Gulab Singh (Sattar 2013 [1977]:13-29).

$\S$ Other important Hindi novels on the Awadh countryside include Rahi Masum Raza's Adha gaon (1966, tr. The Feuding Families of Village Gangauli), which focuses on a clan of Muslim zamindars in a small qasba in the years of WWII and independence and on the devastating effects of Partition and of zamindari abolition on their way of life; the novel delights in reproducing the Urdu-mixed Avadhi of its characters and the traditions of Shi'a festivals. Srilal Shukla's satirical masterpiece Rag Darbari (1968), set in a fictional village in the 1960s, punctures both the nationalist glorification of the village and 'happy peasant' life which grew out of Baden Powell's idea of 'village republics' and M.K. Gandhi's championing of the self-sufficient village community as a counter-model to the corruption of urban and Western modernity, and Nehruvian plans of rural development, with a hilarious deconstruction of public speeches and the public campaign posters that exhort villagers to 'Grow More Grain' - as if they were perversely unwilling to do so-while showing a healthy farmer and his contented, laughing wife (2003 [1968]: 57-58).

** 'ye dagh dagh ujala, ye shab gazida sahar' ('this stain-covered daybreak, this night-bitten dawn') is the first line of Faiz Ahmad Faiz's poem 'Subh-e azadi' ('Freedom's dawn', 1947), registering the disappointment that freedom should bring such bitter fruits (Kiernan 1971:123). All translations from the Hindi and Urdu novels are my own.
} 
who remains a necessary reference point for Hindi and Urdu writers writing about the village and the rural world. ${ }^{\dagger \dagger}$

\section{Premchand}

The parallel history of the novel in Hindi and Urdu neatly dovetails in the towering figure of Premchand (1880-1936), whose substantial output included ten novels and three hundred-odd short stories. A social realist, he wrote about caste discrimination, the exploitation of tenant farmers and rural debt, but also fairly sympathetically about the zamindars caught between increasing demands from the colonial state and the need to maintain their status. A professional writer and a nationalist, it was probably in order to reach a wider audience and to secure better income in the quickly expanding Hindi literary market that Premchand famously switched from writing in Urdu to first translating his Urdu manuscripts into Hindi and then writing directly in Hindi-though he always made sure that his novels were published in Urdu, too.

Two of Premchand's novels deal squarely with the rural world, covering the whole social range from taluqdars to landless labourers, with parallel plotlines in the city and the village. Premashram [The Ashram of Love] (1921) generation of absentee zamindars, one of whom feels the need to extract more rural surplus and cannot afford to be a benevolent paternalist like his father. The tenant farmers in the village protest against his agent's abuses until finally one of them kills him; the court case against them becomes an opportunity to voice their grievances, and they are acquitted. The novel ends optimistically, with the 'good' zamindar brother, who had studied agriculture in the USA, founding a rural cooperative. ${ }^{\S \S}$ Premchand's second and more famous rural novel, Godaan [The gift of a cow] (Hindi 1936, Urdu 1939) is even broader in scope, with a notable absence of collective peasant resistance. Hori, the protagonist, is a tenant farmer who eschews protest and acquiesces to his exploitation and rapid pauperization, unlike his more vocal wife Dhaniya.

While astute in terms of social and psychological characterization, Premchand has been criticized for the 'flatness' of his language and the lack of caste and cultural specificity:

Written in Khari Boli [modern standard Hindi], Godan had villagers of Uttar Pradesh speak a language with few inputs from Avadhi, Bhojpuri or Braj that continued to dominate the spoken universe of north India but were pushed to the margin by the Khari Boli movement since the late nineteenth century. It may be claimed that, in Premchand's world, the region remained devoid of its

\footnotetext{
${ }^{\dagger}$ In an autobiographical essay written in 1991, Shivprasad Singh (b. 1929) recalled that as a student at Benares Hindu University in the late 1940s he had felt closer to Jayshankar Prasad and the Bengali novelist Sharat Chandra, or to Tolstoy, Chekhov and Turgenev, than to Premchand, because of Premchand's colourless (sapat) language. But, 'when the desire to write something unsaid about the village awakened, I encountered Premchand. There was really no alternative to him, not then, not now. For a realist fiction writer, a person who was keen to write about the village, what harbour other than him was there after all? (1995: 19)

\# Premashram was first written in Urdu as Gosha-e afiya ('A Peaceful Corner', probably between 1918 and 1920, see Goyanka, 1973: 62, 64), though the Hindi version he then prepared was published first (by Hindi Pustak Agency, Calcutta, ca. 1921); in Urdu it was published in 1928 by Dar al-Ishat, Lahore.

$\S \S$ Whether Premashram was inspired by the anti-rent peasant agitation in Awadh in 1919-22, which Premchand must have known about but which he does not refer directly to, has been intensely debated (Talwar 1990).
} 
own multi-lingual practices, villages emptied of their caste specificities and their peasant world without their cultural regional moorings (Jha, 2012: 9).

In creating the first novels about rural Awadh, then, Premchand was more interested in social relationships and the ills within the economic, social, and political system than in bringing the oral cultural world of the village onto the page.

Moreover, Premchand was scathing in his moral and aesthetic condemnation of Nawabi culture: even when describing poetic and musical soirées his detachment is palpable and at times tinged with satire, as in his famous story 'The Chess Players' (1927). So while it is safe to assume that subsequent Hindi and Urdu writers all read Premchand (indeed, every Hindi- and Urdu-reading schoolchild does), we shall see that both Shivprasad Singh and Qazi Abdul Sattar choose quite different strategies. And while the three authors considered here all had access to the multilingual oral world of Hindi, Urdu, and English (and in the case of Singh and Abdus Sattar, also Avadhi and Bhojpuri), the ways in which their novels deal with the spoken world and the extent to which they incorporate aural traditions depend to a large extent upon the sensibility and cultural affiliation of each author within their linguistic field.**

\section{The postcolonial Hindi village novel and Alag alag vaitarani}

The first decade of the new nation, the 1950s, saw public discourse on the village shift from one of socio-economic exploitation and injustice due to the zamindari system and rural debt, to one of economic underdevelopment that required planned action by the state. The discourse of underdevelopment is pervasive in the Hindi novel Alag alag vaitarani (1967, but written over a long period), which marks a significant departure from Premchand's generic social realism while simultaneously rejecting the contemporary label of 'regionalist'.

Writing in Hindi about the village in the 1950s meant being classed with the new literary wave of 'anchalik' novels, a term taken from the title of Phanishwarnath Renu's celebrated novel Maila anchal [The Soiled Border] (1954) that came to define normatively Hindi writing about the rural world. Renu himself had called Maryganj, the setting of Maila anchal, 'a symbol of all backward villages' (1995 [1954]: 22). But whereas Renu had then proceeded to show the extreme dynamism at work in the social and political life of the village, foregrounding the role of caste in politics decades ahead of political scientists, Hindi literary critics took him at his word. Since Maila anchal was a choral novel about a remote village in North-East Bihar, far from the centres of modernization, with no clear protagonist, and built on a cyclical narrative pattern richly imbued with local folk culture and traditions, anchalik writing must include these features, in marked contrast to the urban stories of individual alienation and tense relationships that were instead taken to define literary modernity in Hindi. Singh himself recalls that at a literary gathering in 1957, authors writing on the city were called modern, whereas writers on the village were called 'anchalik', rustic (ganvar) and nostalgic of premodern village economy and culture. ${ }^{\dagger \dagger \dagger}$ It was in

\footnotetext{
${ }^{* * *}$ As G.J.V. Prasad has argued, Indian English writers are not so much translating texts from vernacular languages into English, as using various strategies to make their works read like translations (Prasad 1999).

†† In the preface he pleaded: 'However much I try, if readers want to place it in like with anchalik novels, what can I do? Well, my only request is that if you want to use the term anchalik, do so but please do not adopt an anchalik vision'- by which he meant judging the novel according to anchalik criteria. Yet this is exactly what happened: one critic compared Singh's novel to Renu and found it
} 
fact in order to break with this anchalik 'nostalgia' (sammohan), Singh claims, that he wrote Alag alag vaitarani. t\$

Vaitarni is the mythological river flowing between heaven and hell, a river which righteous people see filled with nectar and sinners filled with blood. But in the preface, Shivprasad Singh proposed a new interpretation: if according to mythology the Vaitarni river was formed by Shiva's tears after the death of his beloved wife Sati, these are the tears of a

crazed, exiled, distressed Shiva fighting against the organized injustice of the mob [...] Whenever the quality of auspiciousness (shivatva) is trampled, individuals are deprived of their rights, and truth and justice are disregarded, then the tears of many different people (jan-jan) become a stream which turns into the Vaitarni. It becomes the river of hell. (1967: np)

While the shallow river of the village where the novel is set, one of countless 'lightless villages' (nachiragi mauza), cannot aspire to this grandeur, its many stories of injustice, hardship, and deprivation together create 'many Vaitarnis. '\$§§ What has turned these rural communities into 'lightless villages'? 'Floods, upheavals, war, drought, famine, or something else?' The question is left unanswered here, but it is unaswered in the course of the novel by the strong critique of social disunity and economic stagnation voiced by the positive characters, as we shall see.

Alag alag vaitarani is a sprawling novel of almost seven hundred pages, recalling the 1500-odd pages of A Suitable Boy. Like Maila anchal it is a choral novel, with a large cast of characters, and a shifting point of view. Initially the viewpoint is that of Bullu Pandit, a naïve and obliging poor Brahmin who acts as messenger and general dogsbody and introduces many of the characters at the local fair in the leisurely and crowded first chapter. ${ }^{* * *}$ Though of high caste, Bullu is one of the many villagers who used to be regular retainers of the zamindars and now has to fend for himself after the abolition of zamindari. Zamindari abolition has not translated into a redistribution of land among farmers but has dramatically altered the balance of power in the village, and loosened or severed feudal patronage relationships between the leading zamindar, Bujharath, who lives in the fort-like mansion (chhavni) at the top of the village, and their erstwhile 'subjects' (praja-pauni) in the village: 'earlier all of Karaita's roads led to the chavni' (1967: 47), Bullu thinks, now not anymore: ${ }^{\dagger \dagger \dagger \dagger}$

\footnotetext{
lacking —in folk songs, a clearly delineated local culture, the chirruping of birds (a Renu signature note), village proverbs, and the beauty of nature (Singh, 1995: 20).

$\$+$ In fact, the novel does include a range of linguistic registers, particularly of Bhojpuri, the local dialect spoken by a number of characters, and a number of verses and songs.

$\S \S$ Alag alag means 'many', but its distributive sense implies that these are many different and separate streams: in other words, in the village the individual stories of injustice and deprivation do not add up to a collective struggle but dissipate in personal tragedies.

***** When Vipin comes in after almost 100 pages, it looks like he will be the main focalizer, but the viewpoint shifts again in the following chapter. Vipin's is not the privileged viewpoint.

${ }^{\dagger \dagger \dagger}$ On his part, the leading zamindar Bujharath refuses to perform ritual duties, such as feeding all his retainers khichri on the occasion of Makar Sankranti when they return from bathing in the Ganges: 'A stupid trouble' (wahiyat jhamela), 'Forget about it' (maro goli), 'What's the point of that display (dikhava)? Are we the only ones to carry on ritual customs (rasm-rivaj)? If village people have stopped paying obeisance (salami) and bringing gifts (nazrana), why shoud we continue with all this?', he tells his wife (1967:456).
} 
Times are changing fast. The ancestral solid walls of zamindari are falling down with a gentle push. The whole environment of Karaita is changing in front of one's eyes. Tenants have set aside familiar ties of obligation (khandani laj-sharam) and broken off relations with the chhavni. Now you no longer have tenants queuing up at Dusehra to come and pay their respects (juhar). Nor does the large tray lying at the gate of the chhavni ever tinkle with the coins they offered as gifts. Ahirs have completely stopped giving milk and curds, Koiris have stopped bringing fresh vegetables, Mallahs fish, Julahas chickens and Gareris goats with their salams. This is why at the chhavni they no longer any need to celebrate these occasions with festivities, and whitewash and clean the place. (1967: 32)

Bujharath's wife, Kaniya, acts as a kind of moral sentinel of the village to mitigate her husband's abuses behind the scenes, though she is ultimately not more effective than the virtuous mother in Shab gazida.

Almost every chapter brings in a new character and their story. For example Khalil Miyan or Khalil chacha, practically the only Muslim left in the village, + tt: formerly a wealthy farmer and now a 'defeated man', he tells Vipin: his sons have left (one for Pakistan), and farming has become less and less profitable. This is not directly the effect of zamindari abolition, he claims, but of land tax which forced him to borrow from his Yadav herdsman and ploughman, who then tricked him out of his lands with the help of the land record-keeper, the patwari. ${ }^{\S \S \S}$ Singh skillfully shifts language registers to represent not just idiolects but 'character zones' and caste lifeworlds-Khalil Miyan's Urdu, Vipin's complex thought processes, the brash Yadav policeman Jagesar's abuse-rich Hinglish, young Dalit servant Ghurbinva, and so on.

Three educated youth stand out as representatives of Nehruvian nationalism and developmental discourse, and promise to be ethical agents of socio-economic as well as narrative action. Two are from the village: Bujharath's younger brother Vipin, who has returned after an MA in History, and dagdar (doctor) Devnath, who disgusts his Brahmin father by curing low-caste people in the village instead of setting up a lucrative business in the nearby town. The third is an outsider, the new teacher Shashikant. He initially challenges his superior's view that being posted to Karaita means being 'dumped' in a 'wasteland' (though he himself talks of the village as a 'dead' and 'wretched place', murda... sariyal jagah, 1967: 175). On his first day in Karaita, the children's faces strike him as innocent but also hopeless, and though he sounds enthusiastic and encouraging to them, two months later he reiterates that the school and the village are 'dead', and school life is listless and dull (in English, 1967: 182) and wonders how he can inject life into them. Shashikant is constantly discouraged by the mockery of his headmaster, a seasoned teacher who uses corporal punishment, does not believe in hard work or stimulating the children, and in fact abuses them sexually (something a disgusted Shashikant finds out but does not report). Shashikant's experiment at using cricket for nation-building seems successful at first: in a few months the school acquires a flower garden and a sports pitch, and

\footnotetext{
Wt The tokenistic presence of the benevolent Muslim chacha, uncle, was a constant in Hindi films of the 1950s.

$\S \S \S$ This conversation between Khalil Miyan and Vipin offers the only chance in the novel to discuss the past and present of Hindu-Muslim relations in the village.

***** 'Character zone' for Bakhtin is 'the field of action for a character's voice' which extends 'beyond the boundaries of the direct discourse allotted to him' (Bakhtin, 1981: 316, 320).
} 
with some basic equipment the schoolchildren train and take part in tournaments, with a new sparkle on their faces. But Shashikant's experiment ends badly: one day he's badly beaten and robbed by one of the villagers and decides to leave on the spot. This is emblematic of the other educated would-be modernisers - they all leave.

Three critical events punctuate the flow of individual narratives. The first sets up expectations of Vipin as a man of strong feeling and bold action. Chachiya, an old retainer of Bujharath's mother left with no means of support and unable to pay her debts after her husband's debilitating illness, is threatened with eviction by Bujharath, who is sending his righthand man Khuda Bakhsh with the bailiff. This is a profound breach of village solidarity and the fictive kinship between the two families, and other principled villagers are appalled ('the poor man's house burns and the villain warms his hands,' as the proverb goes, 1967: 113). Chachiya's daughter Pushpa, a childhood playmate (balhiya) of Vipin, defies modesty and begs Vipin to save them. Profoundly ashamed at his brother's action, Vipin borrows the sum from Kaniya without telling her what it is for. The gesture awakens a storm of feelings within him, and Vipin and Pushpa start secretly caring for each other.

The second critical event indicts the sexual predatoriness of the zamindari system (as in Shab gazida), destroys Vipin's romance, and punctures our expectations of Vipin. Not content with having a young Dalit mistress, his brother Bujharath plans to kidnap Pushpa, while his rival Surju hopes to catch him red-handed and have him arrested and publicly shamed. Informed just in time, Vipin, rushes to stop Bujharath from committing the deed and falling in the trap. Bujharath hurts his head badly as he flees, and in order to cover up the incident in front of the villagers and of Kaniya, Vipin claims that it was he who hit Bujharath in a quarrel. Pushpa and Vipin are now caught in separate nightmares: Pushpa's that Vipin may think she was complicit in the plan, Vipin's that his reputation before the village and before Kaniya has been tarnished - how could he hit his elder brother? - and that he cannot hope to bring home Pushpa as his wife. As in Shab gazida, the educated youth's romance is blocked by a family elder. Vipin is reminded of a story his mother used to tell him of a queen whose husband had ordered her to fetch a flower under the sea for a dom to whom he had lost at cards. ${ }^{\dagger \dagger \dagger}$ After a tender and desperate meeting with Pushpa, Vipin remembers the end of the story: the dom grasped the queen and pulled her to his palace under the sea, her cries leaving echoes-who will save her? (1967: 422). Later, when her parents arrange for Pushpa's marriage to another man and she is desperate to see Vipin once more, he stays away. Vipin's cowardice with Pushpa marks him out as a weak man, someone too compromised by his own family and class to be an effective agent of change.

The final critical event, towards the end of the novel, is a violent confrontation between Dalit labourers and high-caste Thakurs due to the high-castes' sexual exploitation of Dalit women. The conflict leads to the death of the wise leader of the itinerant Dalit labour gang, Sarup Bhagat, and confirms the village as a site of unredeemed injustice. Once again, Vipin is called upon to intervene and stop the violence ('It's a frightening flood, bhaiya, stop it. You are the only one who can stop it. Everyone will listen to you,' Jaggan Misir urges him, 1967: 605) but does not—-this time because Kaniya stops him.

Alag alag vaitarani contains lyrical natural descriptions and a great feel for local vocabulary and expressions, justifying Singh's criticism of Premchand's language. Yet in opposition to the celebration of the village in Gandhian nationalism,

${ }^{\dagger+1 \dagger}$ A dom is a man who deals with cremating corpses, a job considered extremely polluting. 
the attitude towards it is one of despair. 'Nothing can change in this village' several characters reiterate, echoing the 'lightless village' (nachiragi mauza) of the preface. This critique of village underdevelopment has an economic side to it and a moral one. Jaggan Misir aptly sums up the economic issues when Vipin also decides to leave the village:

'You're leaving, Vipin Babu, go. Nobody will blame you for it. Our villages these days have only one way-out. Out, and out only. Whoever is good, who can do something, leaves. Good grain, milk, ghee, vegetables leave. Good healthy cattle, cows and buffaloes, sheep and goats, leave. Strong healthy men, with strength in their bodies and energy in their limbs, are drawn away to the paltan, the police, the maletari [military], the mills. Then how can people with brains, educated people, stay? They will also go. They'll have to go. I am not sorry about them [...]' (1967: 674).+1t\$

The young men instead use the language of moral and physical sickness. According to doctor Devnath's words, 'unmanliness, weakness, impotence are the new illnesses' (1967: 437); for Vipin, 'there is probably no village as badnam, poor, wretched, and sick as Karaita. No decent man can live here.' For Shashikant 'it's human beings who have become narrower than before - in their thinking, their hearts and minds, their bodies, and actions' (1967: 444). Is their moral language itself proof of their inability to mobilise the villagers and intervene in the socio-economic structure? Interestingly, it is not the abolition of zamindari, or the political greed of post-independence Congress, which are the problems in Alag alag vaitarni, unlike $A$ Suitable Boy. It is the lack of rural employment and the decline in social and moral solidarity that will stop caste, gender, and economic abuse, which are hollowing the village from within.

The novel's plot arc resembles that of Qazi 'Abdul Sattar's later Urdu novel Shab gazida (1984). Set before Independence, with taluqdars still economically and socially dominant and at the centre of the narrative, Shab gazida features a similar internecine struggle within the zamindari family and a young educated hero who wants to bring about change but is - tragically - prevented from it. Yet whereas Alag alag vaitarani is unnostalgic about the old feudal culture of rural Awadh, much of Shab gazida's textual pleasure comes from evoking precisely that culture.

\section{Shab gazida}

Qazi 'Abdul Sattar (1933-) is known in Urdu mostly for his historical fiction, and his novel on rural Awadh, Shab gazida (1988) can qualify as one such work. The action never moves far from the estate, with the main house (dyorhi, lit. 'threshhold') and the takht (platform, throne) on the main verandah at its core. All the named characters belong to the taluqdar estate of Mirza Nawab of Jamnagar and are in some kinship or subordinate relation to him, from humble servants to local strongmen and other feudal lords.

\footnotetext{
+t। And he continues: 'Yes bhai, they used to leave earlier, too. Often, it was those who could not find work or who feared the abuses (jor-julum) of the zamindars and ran away. But not it's a new kind of endless outflow (anat gaun). Now the only ones who remain are those who do not want to stay but cannot go anywhere. And those who leave are the ones who want to remain but cannot stay' (675).
} 
The meandering geographical description that opens the short novel sets the stage in terms of physical and built environment, significant historical markers, and social world. From the nearby railway station, the road marked by the tracks of heavy cartloads of sugarcane and grain winds its way through a forest, passing by the site of a British cemetery of 1857 . Here two local Muslim and Hindu Rajas (one the grandfather of the current Nawab Mirza, the Raja of Jamnagar) fought together against Col. Thomson, a battle still retold by genealogists (both Muslim mirasis and Hindu bhats) at weddings. The old fort was razed to the ground by the British after the rebellion, but here begin the orchards and fields of the current Raja of Jamnagar. After the bustling village of Jamnagar, with its built market (ganj), weekly bazaar, and Mughal mosque, the description of the walled Jamnagar estate (garhi) evokes Mughal architecture and courtliness. First come the elephant and horse stables, then two gates with armed guards surmounted by a naubatkhana (where the ceremonial drum and other instruments are played on special occasions), then outbuildings for clerks and accountants, various reception halls, and finally the ceremonial building (shish mahal, house of mirrors), on whose verandah stands the takht of the Raja, Mirza Sahab, where he receives visitors and pleaders.

This is a rural world where Muslim and Hindu landowners fight and party together, where both Muslims and Hindus celebrate Muharram and Holi, where Muslim Rajas have Hindu armed guards aplenty and never go out unaccompanied, and where the wealthy moneylender and estate superintendents may fleece the Raja but scrupulously retain a deferential demeanour. Everything in the estate, and in the novel, revolves around Mirza Sahab, who may have left the running of the estate to his superintendent, the clever Rehmat Ali Khan, but will not relinquish control or admit insubordination, even from his son, Jimmy. Mirza Sahab is depicted as the quintessential feudal lord: highly conscious of his status, paternalistic and tyrannical, sexually exploitative, selfish and shrewd in words and actions. Keen to retain autonomy from British interference, he unwittingly shelters his wife's nephew Akhtar, a revolutionary on the run from the police after a bomb case-practically the only echo in the novel of the wider world of politics. ${ }^{\text {}} \$ \S \S \S$

Much of the pleasure of the novel comes from the loving descriptions of the material world of the dyorhi and its elaborate aesthetics - pandans and spittoons of various metals and alloys, food and clothing, refined allusive speech. ${ }^{* * * * * *}$ Every meal takes place among a profusion of trays, plates, and bowls, with watchful servants

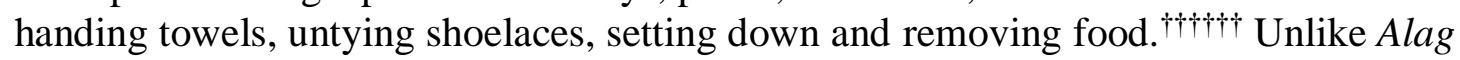
alag vaitarani, we are not privy to characters' thoughts but only to their movements and controlled speech, and this makes us pay attention to any clue their careful performances may reveal.

The story moves slowly. Young, Colvin College-educated Jimmy is back from Lucknow, keen to remedy the breach between his father and uncle, a nearby taluqdar married to Nawab Mirza's sister, and marry their daughter Zubeida (who was

\footnotetext{
$\$ \S \S$ Shab gazida is unusual among the other novels on rural Awadh in paying hardly any attention to nationalist politics: Jimmy's uncle is also a loyalist and Jimmy himself does not hesitate to involve the British Resident in order to stop a dispute between his father and a neighbouring Raja over a point of etiquette from escalating.

******* In terms of language registers, Shab gazida differentiates between the chaste Urdu spoken by all the elite characters and the Awadhi-inflected speech of the Rajput guards and of the women servants, though see below.

titti This emphasis on description of the material culture of a lost world is something the novel shares with S.R. Faruqi's novel Chand tare sar-e asman (another poetic quote for a title, 2006, translated as The Mirror of Beauty, 2013).
} 
educated at home by a British governess). Jimmy is even keener to wrestle control of the estate from Rehmat Ali Khan - who has quietly been making a profit from side deals and expanding his clout. As a local ruffian explains, 'Chote sarkar [the junior lord] is English educated. His style is quite different from bare sarkar's. He keeps account of each guava and phalenda, ${ }^{\text {thtt }}$ while bare sarkar has no head for even elephants and horses' (1988: 46). Jimmy plans agricultural reform for the estate, cares less for supremacy and more for cooperation with neighbouring Hindu taluqdars, and is aware that nationalist politics will threaten their hold on the land, something his father angrily refuses to even contemplate.

But in order to acquire control over the estate, the estate accounts, and the keys to the treasury, Jimmy, who is already formally the heir, has to break Rehmat Ali Khan's hold over Mirza Sahab. As Jimmy explains to his childhood friend Chaudhri Bedhab Singh, a roguish but fiercely loyal Thakur from a nearby village, the real threat comes from within his own house. The story advances like a game of chess, with Jimmy and Rehmat Ali Khan exchanging moves while Mirza Sahab, who sides with his superintendent against his own son, nevertheless does not stop Jimmy's interventions. Together, Jimmy and Bedhab shrewdly dodge Rehmat Ali Khan's threats and are apparently successful in neutralizing him. But in the dramatic denouement, Mirza Sahab commits filicide by coldly feeding Jimmy a poisoned sweet. As in Alag alag vaitarani, we are initially led to expect that the educated youth will bring about change - here in the running of the estate and in feudal sexual politics, there in the economic development and social transformation of the village, but the expectations of change and of purposeful action are frustrated.

While the only thing that the Hindi novel Alag alag vaitarani bemoaned about the loss of zamindari was its patronage that strengthened the social fabric of the village, Shab gazida is poised in a tension between condemning the sexual exploitation and lawlessness of Mirza Sahab's feudal lord and a loving recreation of the rich material, social, and cultural world of feudal rural Awadh, which even modern English-educated Jimmy does not disavow - and which Muslims lost after Partition. We can read Shab gazida's filicide as a statement about the suicidal unwillingness of the Muslim-dominated feudal system of Awadh to renew itself. Partition and zamindari abolition will do the rest.

Yet it is not Nawabi Lucknow that Sattar longs for and evokes in this Urdu novel-Urdu poetry is notable for its absence, and courtesan performances, which represent the fulcrum of Nawabi culture in A Suitable Boy and are completely absent from Alag alag vaitarani, occur frequently here but are only mentioned in passing. It is rather the lost material world of rural Awadh, with its history of social ties between Muslim and Hindu taluqdars and between Muslim taluqdars and their Hindu retainers, and its expressive multilinguality of Urdu and Avadhi. $\$ \S \S \S \S$ While the young educated male characters speak English or Urdu with each other, their ability to speak Awadhi is an asset they use for social cohesion. ${ }^{* * * * * * * *}$ The loss of both these elements-Hindu-Muslim interdependence and Urdu-Avadhi multilinguality-, the novel signals, was a loss for Indian Muslims but also for the postcolonial nation and its culture.

\footnotetext{
+t+t+ a kind of large jamun fruit.

$\S \S \S \S \S$ It is marsiyas (dirges) in the local dialect on popular tunes that women sing for Moharram (Sattar 2014: 120), not the famous and elaborate Urdu ones of Lucknow poets Mir Anis and Dabir.

${ }^{* * * * * * *}$ Significant here is a scene between Jimmy, the young Muslim taluqdar who is the protagonist, and the mother of his Hindu neighbour, with whom he speaks familiarly in Avadhi (Sattar 2014:143).
} 
With its much more selective celebration of music and Urdu poetry as nostalgic symbols of Awadh culture, its strategic splitting between the benevolent paternalism of the Nawab of Baitar and the exploitative cruelty of Rasheed's uncouth petty-zamindar elders, and its distancing descriptions of the village as a cultural, social, and economic wasteland, A Suitable Boy reveals a much greater distance from this rural world.

\section{A Suitable Boy}

'The rural theme has attracted scant attention in scholarship on the Indian novel in English, largely because the setting of Indian novels in English themselves is more often urban than rural. Nevertheless, rural concerns are represented in Indian literature in English', writes Angela Eyre in her comparative study of rural Hindi and English novels (2004: 12; 2005). In common with Hindi novels, she notes, English novels on rural north India treat the agrarian theme politically, thematise the ambivalent involvement of the Congress party and its veniality after independence, and have at least one zamindar who is a member of the Congress party but sides with the peasants. In A Suitable Boy, this is the State minister in charge of the Zamindari Abolition Act, Mahesh Kapoor.

As Eyre has noted, the rural plotline occupies four parts of this sprawling novel. First, the arrival of Mahesh Kapoor's wayward son Maan at the village of Debaria with his Urdu tutor Rasheed, the son of local petty zamindars. Maan has been 'exiled' for a month from the city as a kind of punishment for his persistent attachment to the courtesan Saeeda Bai..$^{\dagger \dagger \dagger \dagger \dagger}$ In Debaria boredom and heat almost drive him insane. But outgoing Maan cannot help but meeting and observing the assorted local characters, and it is through his descriptions that we readers encounter the village. He also meets the young and dynamic Bengali Sub-Divisional Officer Sandeep Lahiri, who delights Maan by taking him on a hunting expedition. This brings him to the nearby town of Baitar and the almost empty dyorhi of his father's friend the Nawab of Baitar, where only a few retainers live. When Maan returns to Debaria and Baitar with his father Mahesh Kapoor during the latter's campaign for the first general elections, his father is surprised at Maan's local knowledge and the goodwill he has earned among the local population. However, Maan's ill-fated stabbing of his good friend Firoze, the son of the Nawab of Baitar, sets the local independent candidate Waris, a retainer of the Nawab's, against Mahesh Kapoor, and by spreading the rumour that Firoze has died Waris manages to sway the elections-there are indications that he will become a new breed of cunning politician.

Given that the Zamindari Abolition Act of 1951 plays a central role in the novel, occupying significant narrative space even in the chapters dedicated to Brahmpur, the extensive rural subplot allows Seth to connect the Congress high politics in the state and at the national level (the Legislative Assembly debates in Brahmpur) and the urban elites with the social world beyond them - the rural world of petty zamindars (like Rasheed's family), land record-keepers, and labouring peasants. Even Nehru comes to speak to Baitar and Salimpur (1993: 1351ff)! The subplot connects - and highlights the yawning gap between — static life in the village and modern life in the city (despite futher differences between Brahmapur and Calcutta). It also connects the official machinery of the state (the Legislative Assembly, again)

${ }^{+\dagger+t \dagger \dagger}$ Maan's feelings towards the village are almost unremittingly negative, and the term 'exile' recurs more than once. Only at the end of his stay he acknowledges that he has developed some fondness for Debaria - and in turn the villagers have become fond of him. 
with its actual, much more limited functioning on the ground, despite the SDO's energy and good intentions. Yet, as with all realist novels that seek to capture the entirety of the social world, what we get is a particular and selective construction of reality.

As Eyre has pointed out, the village of Debaria is described and narrated almost exclusively through Maan's eyes. He sees it as utterly uncomfortable, unspeakably dull and oppressive, devoid of any history, vitality and attraction beyond occasionally natural beauty. The descriptions of the stations along the railway line, of Debaria, or of the nearby qasba of Salimpur are all generic:

Every fifteen minutes or so the train stopped at a small railway station, sometimes in the middle of nowhere, sometimes in a village. Very occasionally it would halt at a small town, the headquarters of a subdivision of the district they were travelling through. A mosque or a temple, a few neem or pipal or banyan trees, a boy driving goats along a dusty track, the sudden turquoise of a kingfisher-Maan vaguely registered these. (1993: 542)

The point here is not that this description is not effective in conveying Maan's unfamiliar and detached gaze (it is), but that this is the only kind of description that we get in the rural subplot, which is much less vivid and animated than the urban sections of the novel.

Once in Debaria, there is little village life beyond the occasional dull visitors and pigheaded factionalism. Instead of the collective life of caste groups and village friendships, with their conflicts, ritual occasions and social and cultural life, instead of politicized tenant farmers, we have the solitary and largely silent Dalit labourer Kachheru, whose very silence marks his disempowerment. 'It is a sign of his lack of power in this novel peopled with garrulous characters that Kachheru very rarely speaks', Eyre notes (2004: 213). Even Rasheed, who resembles the educated youth in the other novels, unlike them is completely alone and pursues a purely individual course of action that antagonises his family and ends in complete failure. His view of the village is of utter waste, and he holds his family directly responsible.

A Suitable Boy is keenly attuned to Nehru's rhetoric of development, tied as it was to industrialization versus agricultural modes of production, and to the progressive state as an agent of 'reform' vis-à-vis traditional society. In the rural subplot, the postcolonial state discourse of development-cum-paternalistic-care is embodied in the young SDO, the young English-educated IAS officer Sandip Lahiri, a Sub-Divisional Officer on his first posting who is clearly set apart from the rural population he's administering and yet earnestly preoccupied with their welfare. $+1+1+14$ By contrast, the Muslim taluqdar and Hindu zamindar/Congress minister are absentee landlords, and the local petty zamindars only seek to minimise the consequences of zamindari abolition and, like local Congress politicians, are not interested in investing in and transforming the rural economy. Tenant farmers are absent from Seth's narrative. As for Maan, he could not be less interested in socio-economic action and reform.

H+1+ Lahiri reads Howards End and listens to Mozart and Beethoven, disdains politicians and is reasonable and balanced: when he explains to Maan that the wolves are forced out of the forests by deforestation, he says 'very sad. Sad for the villagers, sad for the wolves' (1993: 679). His awkward but surprisingly popular speech at the Republic Day celebration mirrors Nehru's performance towards the end of novel. 
With respect to the feudal culture of Awadh, the novel embodies (and contains?) it almost exclusively in two figures: the Nawab of Baitar, who is unwilling and unable to stem post-Partition and post-abolition decline and withdraws into the library. ${ }^{\S \S \S \S \S \S}$ And Saeeda Bai, a consummate performer of the song genres of Hindustani music, ghazals, khyal, thumris and thappas. With Saeeda-again focalized through Maan - this very anglocentric novel engages most passionately with the nonEnglish world of Urdu poetry and endowes it with cultural value. ${ }^{* * * * * * * *}$ Maan's dialogues with Saeeda are supposedly in Urdu, 'translated' in English in a flowery style; he recruits Rasheed and acquiesces to the exile in Debaria for the sake of learning Urdu and becoming literate in it. He delights in the nickname Saeeda has given him, Dagh (lit. brand, mark, blemish), a typical Urdu poetic penname. As in the case of the singer Ustad Majeed Khan, descriptions of Saeeda's performances are genuinely full of admiration. And she is sympathetically portrayed as trying to manage her transition as an elite woman performer in this post-feudal world.

If A Suitable Boy engages with the culture of Awadh, then, it is only in terms of a distillation of Hindustani music and Urdu poetry, and that too largely in urban settings. (Maan finds no sympathetic teacher of Urdu love poetry in Debaria.) Saeeda's Baitar performances are mentioned only in the past tense, and in fact she performs publicly only once in the novel, at Mahesh Kapoor's Holi celebrations early on, though she still entertains private clients who belong to the old elites. In Debaria or Baitar, there are no community festivals depicted, no radical Bhakti poetry, no Hindi education and intellectual life of any kind, barring political speeches. ${ }^{\dagger \dagger \dagger \dagger \dagger \dagger}$ This makes the gap between the city — with its University and student life, Legislative Assembly and High Court, its English-educated middle classes, bookshops and Shakespearean theatricals - and the village of Debaria and qasba of Baitar with very little to speak of for themselves, even at a human level, even wider. 'How distant these worlds appeared' (1993: 723), thinks Maan, and while this is partly the result of his view, there is nothing, apart from the instrumental electioneering, that suggests otherwise.

\section{Conclusion: Reading the novels together}

An 'entangled comparative reading' of these three novels helps us bring into better focus how their depiction of rural Awadh can be read along the complex matrix of language, education, literary habitus and aesthetics, social position, language-specific literary debates and political current. While it would be simplistic to identify these

\footnotetext{
$\S \S \S \S \S \S$ The novel is more ambivalent towards the Nawab's sister-in-law and Muslim League politician Begum Abida Khan, who campaigns in favour of retaining Urdu as a state language in the Legislative Assembly and argues against the Zamindari Abolition Act which, she argues, will mean the end of Awadh culture - 'it is we zamindars who have made this province what it is - who made it strong, who gave it its special flavour' (1993: 307). As a fearless, and the only, female politician in the novel she earns our admiration, but as a communalist who makes instrumental use of her community's minority status while she herself is an economic parasite and is disinvested from that culture, her shrill voice of opposition does not find favour with the novel's overall perspective (see also Srivastava 2008: 55-56). The only aural traditions referenced are the devotional song (bhajan) at gentle Mrs Kapoor's funeral, uth ja muazfir, Rise traveller, which is translated in full (1993: 1336), and the wedding songs before Lata's marriage, which are paraphrased (1993: 1459-60). By contrast, English poetry is quoted profusely throughout. Among Hindi genres, apart from the bhajan, the only genre references is the political speech (e.g. the Congress Socialist's candidate, 1993: 1278-83).

$+1+1+1 \dagger$ Maan's tiger-hunting expedition with the Deputy Collector-who has organized it not as a colonial sport but in order to rid local villagers of a man-killer - is a curious conflation of Raj and Awadh tropes, and ends inconclusively.
} 
different positions as determined by the language the novels are written in, language and cultural affiliation do go some way towards providing a key to how they construct their social and aesthetic worlds.

So despite its claim not to be an anchalik novel, Alag alag vaitarani partly reproduces the anchalik departure from Premchand's social realism by giving voice to a large number of village characters and refusing the lure of having the educated young as protagonists and agents (like Maila anchal, and unlike Nagarjun's Nai Paudh). In line with Marxist analyses of the time, the novel develops a critique of economic, caste, sexual and human injustice and underdevelopment, and indulges in no nostalgic description of the feudal culture of the past: the chhavni, the equivalent to Shab gazida's dyorhi or A Suitable Boy's Baitar Fort, is never recalled in its past glory, nor are there any mentions of nautch or musical performances. The aural traditions referenced are rather the devotional song-poems of Kabir and Shivnarayan, the oral epic Chandayani, and other songs. Khalil chacha is the only character in Alag alag vaitarani to quote Urdu poetry.

But Urdu poetry is also interestingly absent from Shab gazida, which prefers to mention rural Muharram celebrations, as well as Nautanki popular theatre at Dussehra 'for the sake of the Hindu subjects' (Sattar, 1988: 63). It is this difference from the urban Nawabi culture of Lucknow, with which Urdu is regularly associated (as indeed it is in A Suitable Boy), that interests Sattar.

What is at stake in these depictions of the village and rural life is their place in national imagination and postcolonial state-building. While Alag alag vaitarani is a novel about contemporary life and Shab gazida and A Suitable Boy are historical novels, all of them are concerned with the future of the rural world and its possibilities (or lack of them). For Shab gazida, spatially still centred on the dyorhi, the future is the end of this interconnected feudal world, a dream of independence stained by the night of partition, as in Faiz's poem. For Alag alag vaitarani and A Suitable Boy, the future of the rural world in post-independent India is bleak, despite the rhetoric of development. Yet if this is a 'lightless village', the Hindi novel suggests, it is nonetheless rich with humanity, no longer centred on the zamindars' chhavni but among the smaller people of the village. Rural development - or rather the lack of it - is at the heart of Alag alag vaitarani, intensely debated by the villagers and enacted by narratives of individual unemployment, impoverishment, and outmigration. No specific sense of the village - apart from a month of exile or a constituency for the urban characters - emerges in A Suitable Boy, whose centre of gravity is definitely the Hindu urban middle class. Here socio-economic underdevelopment is unrelieved by any cultural life or village community. While stemming from a different position vis-à-vis the rural world, then, Seth is just as, if not more, negative about rural development as Singh. But what for Singh is an open and burning question, for Seth is a historical fact.

So do these Hindi, Urdu, and English novels share any common ground, do they draw upon common aesthetics, ideas, and sensibilities? Both Alag alag vaitarani and Shab gazida are attuned to local speech, rural song and poetic repertoires, and village fairs and festivals, though for different reasons, as explained above. But whereas Urdu is the default language of educated intercourse among Muslims and Hindus, Urdu is almost completely absent from Alag alag vaitarani, and diglossia here is between modern standard Hindi (which the educated characters and the narrator use) and the local dialect, Bhojpuri, apart from a few English words of common use. As we have seen, Seth's English-centric novel bypasses village culture, village speech (with a tiny exception) and Hindi completely, and focuses on Urdu 
poetry, Hindustani music, and the figure of the courtesan as emblems of the passing culture of Awadh. Despite their different takes on zamindari, then, the Hindi and Urdu novels valorise the oral culture and social interdependence of rural Awadh, which the English novel does not see it, and both the Urdu and English novels express nostalgia for the social and material sophistication of the zamindari elite. So while all three novels are invested in secularism and Hindu-Muslim coexistence, their social imaginations differ starkly.

Finally, while all three novels can be categorized as realist, their realism differs significantly in texture and aim. Alag alag vaitarani's realism focuses (unlike Premchand's) on the specificity of idiolect and village speech, on descriptions of local nature, and on inner dilemmas and dialogues. Shab gazida's is an evocation of the past, and as we have seen focuses on the surfaces of material culture and the repeated and ritualized gestures of established socio-cultural practice. A Suitable Boy has been characterized as a 'return' to realism after Rushdie's postmodern pastiche and Seth's own cosmopolitan novel in sonnets (The Golden Gate, 1986); its realism consists of a omniscient and distant narrator balancing carefully between particularized description and typification (the village hut, the railway station, the peasant), and offering quickbrush character depictions and equally swift comments about each idiolect. This very broad range of characters and lifeworld and the authorial balance and control resemble in scope not just George Eliot, to which Seth has been compared, but also Premchand. Thus, whereas in the 1950s Shivprasad Singh moved away from Premchand's rural novels, an inevitable reference for anyone writing on the village in Hindi and Urdu even now, forty years after him Seth's sweep, relative distance, and pessimism about the rural world ironically bring him close to Premchand's last novel, Godan (1936).

9500 words ca.

\section{References}

Abdul Sattar, Q. (2013 [1977]) Pital ka ghanta. Delhi: Educational Publishing House.

Abdul Sattar, Q. (2014 [1988]) Shab gazida, Delhi: Educational Publishing House.

Abdul Sattar, Q. and Rashid A.R (2014) Qazi abdussattar, asrar o guftar. Delhi: Arshiyah Publications, 2014.

Bakhtin, M. (1981) The Dialogic Imagination: four essays, edited by Michael Holquist and translated by Caryl Emerson and Michael Holquist. Austin: University of Texas Press.

Datta, A. (1987) Encyclopaedia of Indian Literature, Vol. 1, Delhi: Sahitya Akademi.

Eyre, A. (2004) 'Land as Legislative Space in Vikam Seth's A Suitable Boy and Phanishwarnath Renu's Mailā ãncal", in Prasad, G.J.V., ed.Vikram Seth: An Anthology of Recent Criticism, Delhi: Pencraft International, pp. 142-151.

Eyre, A. (2005) Land, language and literary identity : a thematic comparison of Indian novels in Hindi and English. Unpublished $\mathrm{PhD}$, SOAS, University of London. 
Faruqi, S.R. (2006) Chand tare sar-e asman. New Delhi: Penguin. Translated by the author as The Mirror of Beauty, New Delhi: Penguin, 2013.

Ghiyasuddin, M. (2006) Nazzr-i qāaż 'abdussattār. Delhi: Educational Publishing House.

Goyanka, K.K. (1973) Prem Chand's Craftsmanship in His Novels. Delhi and Allahabad: Saraswati Press.

Jha, S. (2012) 'Visualising a Region: Phanishwarnath Renu and the Archive of the "Regional-Rural" in the 1950s', Indian Economic Social History Review, vol. 49, no. 1, January-March, pp. 1-35.

Kiernan, V. (1971) Poems by Faiz, translated, with an introduction and notes, by Victor G. Kiernan. London: George Allen and Unwin.

Laachir, K. (2016) 'The aesthetics and politics of "reading together" Moroccan novels in Arabic and French', The Journal of North African Studies, vol. 21, no. 1, pp. 1-15.

Orsini, F. (2002) 'India in the Mirror of World Fiction', New Left Review, vol. 13, pp. 75-88.

Prasad, G.J.V. 'Writing Translation: The Strange Case of the Indian English Novel', in Bassnett, S. and Trivedi, H. (eds) Post-colonial Translation: Theory and Practice, London: Routledge, 1999. Pp. 41-57.

Premchand. (1960 [1936]) Godaan. Allahabad: Sarasvati Press. Urdu edition Gaudaan. Delhi: Jamia Millia, 1939. Translated from Hindiby Gordon Roadarmel, The Gift of a Cow. Bloomington : Indiana University Press, 1968.

Premchand. (1928) Gosha-e 'afiya. Lahore: Dar al-Ishat.

Premchand. (1962 [1921]) Premāśram. Allahabad: Hans Prakashan.

Premchand. (1989) The Chess Players and other screenplays. With a translation of the short story by Rupert Snell. London: Faber.

Raza, R.M. (1992 [1966]) Adha gaon. New Delhi: Rajkamal Prakashan. Translated by Gillian Wright as Rahi Masoom Reza, The Feuding Families of Vilage Gangauli. New Delhi: Penguin India, 1994.

Renu, P. (1995) Maila anchal (1954), in Yayavar, B. (ed.) Racanavali, vol. 2, New Delhi: Rajkamal Prakashan.

Seth, V. (1999 [1993]) A Suitable Boy. London: Phoenix.

Shukla, S. (2003 [1968]) Rag darbari. New Delhi: Rajkamal Prakashan. Translated by Gillian Wright as Shrilal Sukla, Raag Darbari. New Delhi: Penguin India,1992.

Singh, S. (1967) Alag alag vaitarani. Allahabad: Lokbharati Prakashan. 
Srivastava, N. (2008) Secularism in the Postcolonial Indian Novel : National and Cosmopolitan Narratives in English. London, New York: Routledge.

Talwar, V.B. (1990) Kisan, rashtriy andolan aur premchand: 1918-1922. Nai Dilli: Northern Book Centre. 